\title{
Manifestations of culture and cultural integrity of indigenous people
}

Latayan, Joeffrey C. $\bowtie$

Laguna State Polytechnic University, Philippines (mariangmakiling2017@gmail.com)

Tan, Consorcia S.

Laguna State Polytechnic University, Philippines (consortan22@gmail.com)

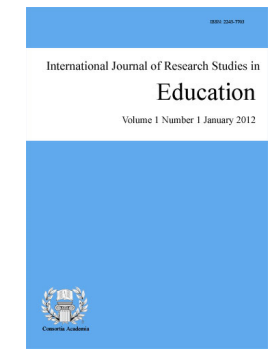

ISSN: $2243-7703$ Online ISSN: 2243-7711

OPEN ACCESS

\section{Abstract}

The research intended to determine correlation between manifestations of culture and cultural integrity. Manifestations of culture were determined using frequency count. Cultural integrity was determined using Likert scale and statistical mean. Manifestations of culture in terms of knowledge, beliefs, values and norms indicated behaviors and actions mostly signifying IP closeness to and dependence on nature as well as the possession of communalist and animist traits. Cultural integrity in terms of knowledge, beliefs, values and norms were somewhat high. Correlations were found between manifestations of culture and cultural integrity in terms of knowledge, beliefs, values, and norms. The researchers concluded that there were significant relationships between manifestations of culture and cultural integrity in terms of IP knowledge, beliefs, values, and norms. They recommended that the IP and concerned agencies prioritize revitalizing IP knowledge particularly those concerning spiritual and religious rituals and practices. Future researchers on cultural manifestations, cultural integrity and other similar topics were advised to replicate and apply the framework and methodology of research be it on IP or non-IP settings. Moreover, future researchers were advised to include other cultural elements such as artifacts and language as variables of manifestations of culture and cultural integrity.

Keywords: manifestations of culture; cultural integrity; knowledge; beliefs; values; norms 


\section{Manifestations of culture and cultural integrity of indigenous people}

\section{Introduction}

Though considered as one of the poorest sectors in the global community, the indigenous peoples (IPs) are bearers of indigenous and local knowledge, beliefs, and values that are of immense significance to mainstream society (Manongdo, 2018). IP knowledge in agriculture, fisheries, flora and fauna, climate patterns and local medicines and healing techniques are contributing significantly to societal development (Watene \& Yap, 2018; \& Popp, 2019).

It is a sad fact, however, that IP cultures are threatened by the influx of foreign and mainstream cultural impositions (Rose, 2016). The IP, since time immemorial, have been subjected to manipulation and exploitation by intruders, colonizers, and imperialists. Their lands and natural resources have been usurped and appropriated by dominant entities such as multi-national corporations, governments, and mainstream ethnic groups. Their traditional cultures have been severely altered by proselytizers, materialistic economic developers, and unscrupulous tourism agents. Throughout history, the world has seen countless cases of ethnocide and genocide inflicted against the indigenous (Kingston, 2015).

Against the backdrop of exploitation and intrusion, the IP bear the right to maintain and manifest their culture. The IP's right to cultural integrity has to be promoted for the protection of IP identity, heritage and community (IPRA, 1997; Philippine Constitution, 1987; \& UN Declaration on Indigenous Peoples Rights, 2007).

\subsection{Background of the study}

IPs native to the region of Calabarzon are the Umiray Dumaget and the Hatang Kaye speakers of Southern Sierra Madre. They are mostly found in the northern part of the province of Quezon as well as in the province of Rizal. A few of them are also found in the uplands of the province of Laguna. Other IPs in Calabarzon include the Aytas of the Tayabas Isthmus, the Agtas of Alabat Island, and the Katabagans of Bondoc Peninsula (SIL, 2019).

The indigenous people in this research are located in Brgy. Lumutan, General Nakar, Quezon. Lumutan is bounded in the north by Brgy. Mahabang Lalim and in the east by Brgy. Pagsangahan. The barangays in the north and east of Lumutan are parts of General Nakar. In the south, it is bounded by Brgy. Daraitan. In the west, it is bounded by Brgys. Laiban, Mamuyao and Santa Ines. The barangays south and west of Lumutan are parts of Tanay, Rizal (Wikimapia, 2019).

Lumutan is the only barangay in General Nakar that is IP dominated. Two IP groups are in the area- the Umiray Dumaget and the Hatang Kaye speakers. Descending from the original inhabitants of the barangay, the latter are comparatively more dominant in terms of numbers. Most of them still live the semi-nomadic way of life transferring from one place to another when situation requires them to do so. Aside from farming and fishing, the Hatang Kaye speakers also engage in hunting and gathering activities (Latayan, Cervantes and Silao, 2013).

\section{Review of related literature}

According to Spencer-Oatey (2012), manifestations of culture have different layers of depth. To analyze the culture of a particular group or organization, it is necessary to distinguish three fundamental levels on which culture manifests itself. These levels are: observable artifacts, values, and basic underlying assumptions. When one joins an organization, he observes and feels its artifacts. To analyze why members behave the way they do, researchers often look for the values that govern behavior, which is the second level of manifestations of culture. 
To really grasp the culture and ascertain more completely values and behavior, it is important to delve into the underlying assumptions, which are usually unconscious but which actually determine how group members perceive, think and feel. These assumptions are learned responses that started as espoused values. As value evolves as behavior, and as behavior begins to solve the problem which ushered it in the first place, value gradually transforms into an underlying assumption about how things really are. As assumption is increasingly being taken for granted, it becomes detached from awareness. Taken-for-granted assumptions are more potent than espoused values because they are comparably less debatable and confrontable.

Popp (2019) opined that across ages, the IP depends on their knowledge of the natural environment. Many plant and animal species were domesticated by indigenous peoples and are now benefiting the entire humanity. The IP have been responsible for the development of many technologies and have substantially contributed to science. Means of gathering scientific knowledge varies from culture to culture. Indigenous science is comprised of traditional knowledge and indigenous views. Non-indigenous scientific means are usually called Western science. Indigenous and non-indigenous approaches contribute substantially to modern science. Indigenous views are holistic and anchored on interconnectedness, reciprocity and the greatest respect for nature. Western and indigenous science approaches and views have their strengths and may complement each other. As an indigenous scientist specializing in combining traditional environmental knowledge and wildlife ecology research, the author came across many examples where blending both approaches resulted in excellent contributions to modern science.

Anthony (2019) found that the largest religion in the Philippines in terms of membership is Roman Catholicism. It is followed second by Protestantism, third by Islam, and, then, fourth by other types of Christianity. However, the author also mentioned that indigenous religious traditions have been in the country centuries before the introduction of Islam and Christianity. The most predominant of these traditions is animism, the belief that both living and non-living things have spirits. With regards to influence, other religions including the predominant Roman Catholicism, have adopted animism in combination with its own beliefs. Such situation is known as religious syncretism.

Stavropoulos (2019) emphasized that there is no single IP culture but there are common threads in the traditions of native peoples that are worth remembering and integrating into conservation work. The author asserted that a lot of IP values could assist in addressing the fundamental social and ecological issues of our times. The IP provide conservation guiding principles to society. In particular, the indigenous values worth considering are the Seventh Generation Principle, Walking Softly on the Earth, and Respect, Humility, and Tolerance.

The Seventh Generation Principle states that people should make decisions about how we live today based on how our decisions will impact the future seven generations. People must be good caretakers of the earth, not simply for themselves, but for those who will inherit the earth. Ages before contemporary terms like "carbon footprint," "green economy," and "sustainability" were used, the IP believed in living in respectful balance with all life. Before engaging in potentially harmful activities, people must consider the long-term consequences to the environment. Though not merely confined among IP, the values of respect, humility, and tolerance are essential and extremely useful in conservation efforts. IP consider respect as essential to healthy and balanced relationships.

Legros and Cislaghi (2019) investigated how multidisciplinary reviews of social norms theory came up with a large body of literature. Four thematic areas of investigation emerged as the authors explored the articles that made it through screening. The authors identified points of contention and agreement regarding whether social norms are individual or collective constructs. They suggested that these two approaches might be of use to scholars and practitioners. The second aspect of investigation relates to the paths through which norms affect people's actions. Points of contention and agreement related to whether one or multiple paths lead from norms to action. The paths in the reviews were grouped into three categories: norms providing value-neutral information, 
norms producing external obligations, and norms turning into internal obligations. The third aspect related to the life stages of social norms was on how these norms form, survive, and dissipate. Finally, the fourth and last aspect of investigation related to the group relevance to the study of social norms.

Wiessner (2011) claimed that IP are vulnerable organic groups with special relationships to their ancestral lands. International legal measures have emerged to ensure protection of IP and are created to respond to IP needs and aspirations. Its policy bases are the goal of cultural diversity, the general public's enjoyment of IP artistic products, and the IP lessons for dealing with nature and life in general. These measures intend not only to protect the IP against physical and legal encroachments but also to protect their languages and rituals. These measures also require governments to foster the education of indigenous people in their native language, the inclusion of their culture in government media, and the development of their own media for the enrichment of their culture.

Latayan, Cervantes, and Silao (2014), in their study conducted on the IPs of an upland sitio in Tanay, Rizal, established the relationships of cultural integrity rights, community development, and quality of life. The study also looked into the effects of demographic profile on the three variables of research. Ways of asserting cultural integrity included livelihood and everyday life activities, use of language, answering surveys conducted by development organizations, holding of IP council meetings, making proposals presented to indigenous people council, helping parents and elders in everyday activities, doing native arts, cooking native food, using tree barks and other indigenous natural materials, making proposals to the National Commission on Indigenous Peoples, asking support from outsiders, revering sacred grounds, worshipping and calling on the god of all people Makidapat, worshipping elements in nature, safeguarding or watching over sacred objects and sites, using sacred objects such as the native betel nut container, constantly living the indigenous ways, applying indigenous knowledge, prohibiting outsiders from doing collections of materials, requiring permissions before collections, prohibiting collection of biological resources, attending trainings and seminars conducted by local governments and outsiders, and use of organic fertilizers and pesticides.

\section{Theoretical framework}

Bulgan (2014) and Lenkeit (2011) attribute the most enduring theory of culture to the nineteenth century English anthropologist Edward Tylor, who defined culture as a complex whole which includes knowledge, belief, art, law, morals, customs, and any other capabilities and habits acquired by people as members of society. In this sense, culture pertains to human creations in abstract and concrete forms. Panopio (2006) identifies the major elements of culture as knowledge, beliefs, values, norms, and materials. Manifestations of these elements exist in the tangible (artifacts) and intangible forms (rituals, practices, habits, customs, traditions, language, etc.).

Hofstede, Hofstede, and Minkov (2010) view manifestations of culture as having levels such as values, rituals, heroes, and symbols. These abstract concepts are expressed as practices which are readily observable to the outsider. These elements give the cultural carriers identity making them distinct from other groups. According to Amos (2004) and Latayan, Cervantes, and Silao (2014), IP cultural integrity is anchored on IP rights. These rights include the right to protection of indigenous culture, traditions and institutions, recognition of cultural diversity, right to religious and cultural sites and ceremonies, and right to indigenous knowledge systems and practices. Behaviors and actions that promote these rights strengthen cultural integrity.

In this study, culture is viewed as a composite of knowledge, beliefs, values, and norms. Manifestations of these elements occur as human creations in concrete and abstract forms (Bulgan, 2014; Hofstede, Hofstede, \& Minkov, 2010; Lenkeit, 2011; O’neal, 2006; Oatey, 2012; Panopio, 2006; \& Spencer-Oatey, 2012). Culture that is stable has integrity. The unbroken connection between cultural elements and the actions, behaviours, and objects originating from these elements is essential to cultural integrity (Root, 2018). Thus, manifestations of culture and cultural integrity are related in a complementary way. An increase in the occurrence of manifestations of culture results to an intensified cultural integrity and vice-versa (Latayan, 2020). 


\subsection{Statement of the problem}

This study intended to explore manifestations of culture and cultural integrity and the relationships existing between the two variables. Specifically, this study sought to answer the following:

$>\quad$ What is the manifestation of culture of the IP in terms of: knowledge, beliefs, values, and norms?

$>$ What is the cultural integrity of the IP in terms of the aforementioned cultural elements?

$>\quad$ Is there a significant relationship between the manifestations of culture and the cultural integrity of the IP?

\subsection{Hypothesis}

The statement of the problem generated the hypothesis that there is no significant relationship between the manifestations of culture and the cultural integrity of the IP.

\subsection{Scope and limitation of the study}

This study views and explores culture as a phenomenon comprised of elements including knowledge, beliefs, values, and norms. Other elements such as artifacts and language are not covered in this research. The IP considered in this research are the Hatang Kaye speakers residing in Brgy. Lumutan, General Nakar, Quezon.

\subsection{Significance of the study}

This study is expected to benefit the IP by promoting cultural revitalization. Cultural revitalization is expected to promote the identity and the betterment of lives in the IP community. Future researchers on cultural manifestations and cultural integrity will benefit from this study since this contains theoretical and conceptual frameworks and methodology that are appropriate for their research.

\subsection{Definition of terms}

Beliefs - These are embodiments of people's perception of reality and include the primitive ideas of the universe as well as the society's empirical view of the world. Beliefs such as superstitions, and those that relate to philosophy, theology, technology, art, and science, are usually incorporated into the whole vast body of knowledge which has been accumulated through time (Bulgan, 2014). Beliefs are operationally defined in this research as the political, economic, and religious views of the IP on how to maintain and develop their community.

Cultural Integrity - Cultural integrity refers to the unity or wholeness of culture. It also refers to autochthonous cultural traditions and to the possibility of aesthetic, social, and ceremonial meanings existing outside the system of capitalist exchange. Integrity retains an idea of cultural wholeness and of a relatively unbroken connection between the image or object and the culture in which it is made and used (Root, 2018). Operationally, cultural integrity pertains to the unity or wholeness of IP knowledge, beliefs, values, and norms which are assessed based on the levels of agreement concerning the wholeness of each element of culture which is to be ascertained through a number of indicators.

Culture - This refers to that complex whole which includes knowledge, belief, art, morals, law, custom, and any other capabilities and habits acquired by man as a member of society (Lenkeit. 2011). In this research, culture is reduced to its intangible elements, namely, knowledge, beliefs, values, and norms.

Knowledge - This is the totality of what has been learned (Bulgan, 2014). In this research, kinds of knowledge considered are natural, technological, supernatural, and magical knowledge which are unique to the 
IP.

Manifestations of Culture - These pertain to the representation of the intangible elements of culture, namely, knowledge, beliefs, values, and norms (Bulgan, 2014; \& Lenkeit, 2011). In this research, manifestations of culture are ascertained through the frequencies of representations of the elements of culture.

Norms - These are accepted standards or ways of behaving or doing things that most people agree with (Cambridge, 2020). In this research, norms considered and ascertained are IP council laws, folkways, and moral rules.

Values - These are abstract concepts of what is important and worthwhile. These values are the bases of our judgment of what we consider beautiful or ugly, desirable or undesirable. They are the standards by which persons, individually or in a groups, define their goals, select alternatives and judge others as good or bad (Bulgan, 2014, del Castillo, 2013). In this research, values considered and ascertained are communalism, environmentalism, and spirituality.

\subsection{Methodology}

The correlational method of research was utilized to determine the existing relationships between manifestations of culture and cultural integrity. The respondents were 251 adult indigenous people residents of Brgy. Lumutan, General Nakar, Quezon Province. Simple random sampling was the sampling technique used. The research instrument utilized was a self-made survey interview questionnaire divided into three parts. Part I was intended to determine the manifestations of IP culture in real world representations as well as in frequencies. Part II was composed of items with Likert scales intended to determine the levels of agreement of cultural integrity. Levels of agreement were disagree for a score of 1 , slightly agree for a score of 2, agree for a score of 3 , and strongly agree for a score of 4 .

The instrument was pilot tested on thirty (30) adult IP residents of a nearby sitio in an adjacent barangay. The pilot test responses for manifestations of culture were subjected to Cronbach Alpha which yielded a .952 level indicating high reliability. The pilot test responses for cultural integrity were also subjected to Cronbach Alpha which yielded a .939 level indicating high reliability. Frequency was used to ascertain manifestations of culture. The mean levels of agreement were computed to determine the levels of cultural integrity. The levels of cultural integrity had the following verbal interpretations: low (1.00-1.72), somewhat low (1.73-2.48), somewhat high (2.49-3.24), and high (3.25-4.00). Pearson correlation was used to determine significant relationship between manifestations of culture and cultural integrity of the IP. Levels of correlation were determined using the following verbal interpretations: very low ( \pm 0.00 to \pm 0.19$)$, low $( \pm 0.20$ to \pm .39 ), moderate $( \pm 0.40$ to \pm 0.59 ), high $( \pm 0.60$ to \pm 0.79$)$, and very high $( \pm 0.80$ to \pm 1.00$)$.

\section{Findings}

As shown in Figure 1, 243 of the respondents mentioned pamamana or spearfishing as a manifestation of IP Knowledge; 242 mentioned pagbabakal, a process of planting rice using an iron-tipped pole; 240 mentioned pamumulig or fishing using apron; 221 mentioned pangangahoy or harvesting lumber; 218 mentioned pangangaso or hunting; 215 mentioned harvesting boho; 196 mentioned pamimiwas or hook and line fishing; 180 mentioned sawali-making; 158 mentioned collecting wild honey; 55 stated knowledge of the ancestral land; 53 stated vegetable gardening; 52 stated planting fruit-bearing trees; 29 stated raising backyard animals; 14 stated mining; and 13 stated paminhi, a planting ritual.

These findings on IP knowledge are supported by the articulations of Popp (2019), Anthony (2019), Stavropoulos (2019), and Weissner (2011) that considered indigenous knowledge as mainly the result of interaction between the IP and the natural environment. As seen from the data, most manifestations of culture in terms of knowledge are concerned with carving out of living from the natural environment.

64 Consortia Academia Publishing (A partner of Network of Professional Researchers and Educators) 
Figure 1. Manifestations of culture in terms of knowledge
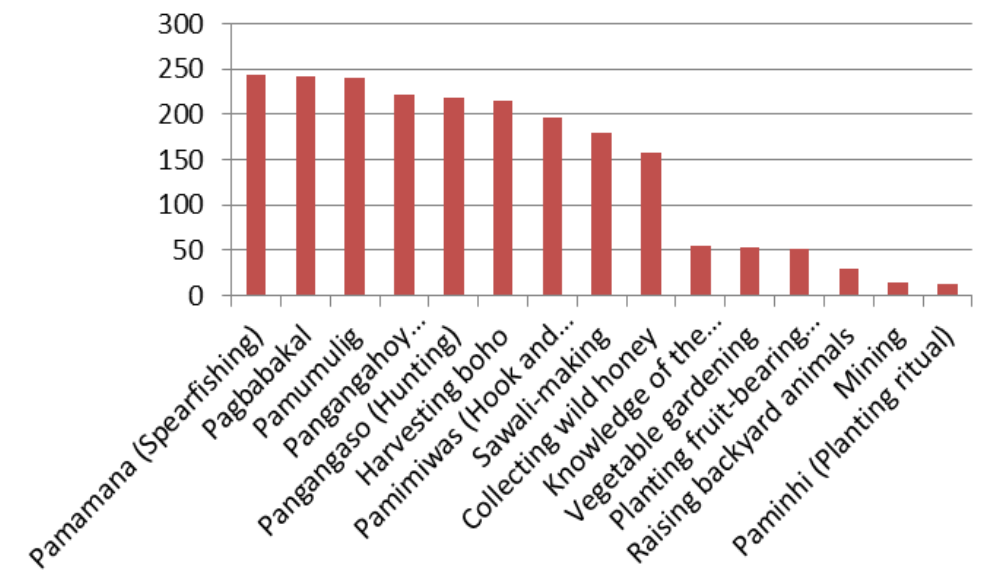

Figure 2 shows that 242 respondents mentioned strong faith in the Creator or Makidapet as a manifestation of IP Belief; 241 mentioned belief in nature spirits; 155 mentioned belief in IP leadership and governance; 151 mentioned belief in indigenous ways; 77 stated belief in democratic ways; and 42 stated belief in people-centered and nature-friendly development.

These findings on the IP beliefs in Lumutan are supported by the articulations of Anthony (2019) and Stavropoulos (2019) concerning what the IP consider as real. IP concept of reality is associated with their religiosity, reverence for nature and communalism. Despite the dominant worldview of the mainstream society, these age-old beliefs still linger among the IP of Lumutan.

\section{Manifestations of Culture in Terms of Beliefs}

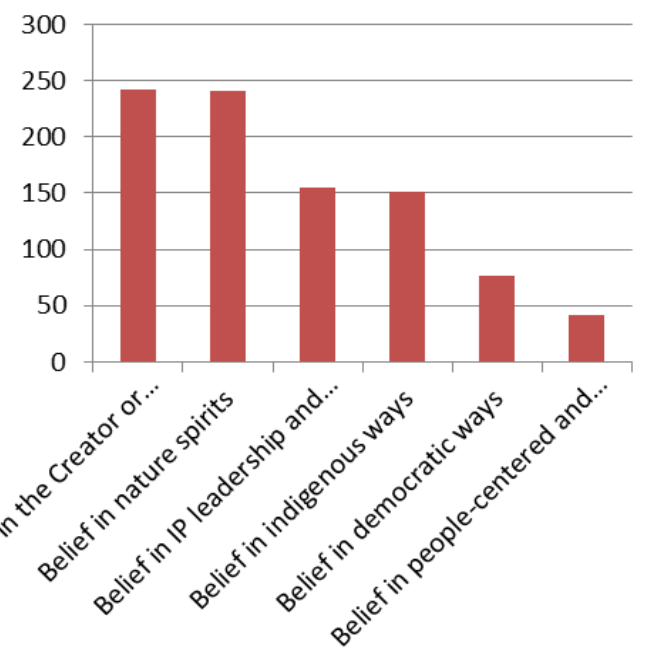

Figure 3 shows that 243 respondents mentioned pakikipagkapwa or communalism as an identifiable IP Value; 242 mentioned familism; 240) mentioned fear of the Creator or Makidapet; 239 stated pakikisama or fellowship; 232 stated reverence for nature; and 167 stated desire for peace.

The findings showing that the IP possessed values of communalism, familism, religiosity, fellowship, and reverence for nature are supported by sources such as those of Anthony (2019), Latayan, Cervantes, and Silao (2014), and Stavropoulos (2019). Therefore, the IP of Lumutan, in terms of beliefs, have similarities with other IPs. 
Figure 3. Manifestations of culture in terms of values

\section{Manifestations of Culture in Terms of Values}

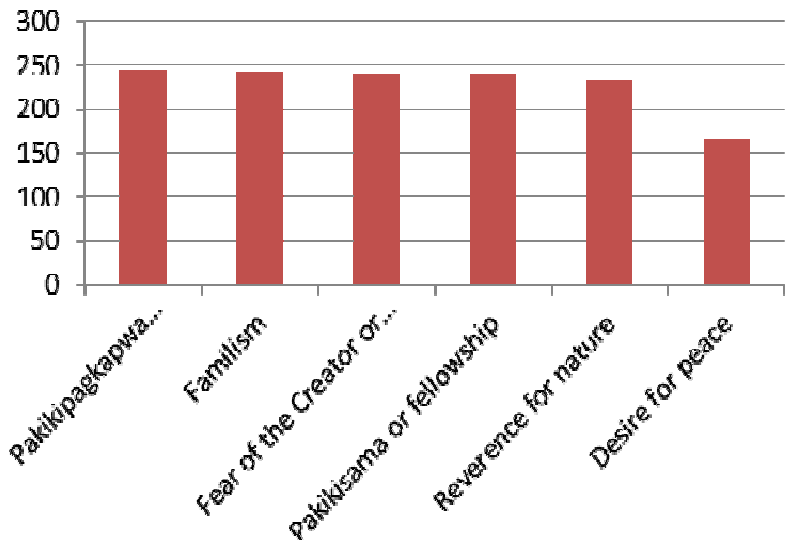

Figure 4 shows that 246 mentioned the implementation and observance of IP law as a manifestation of IP Norms; 151 mentioned conservation of the river and streams; 150 mentioned conservation of trees and other plants; 148 mentioned conservation of wildlife; 147 stated reverence for sacred grounds; 108 stated penitensya or self-flagellation; 93 stated halang-halang, a marriage ritual; and 88 stated pamamanhikan, a practice during courtship.

IP norms such as conservation of the natural environment, reverence for the sacred, and observance of rituals and practices are articulated in the works of Anthony (2019), Latayan, Cervantes, and Silao (2014), Stavropoulos (2019), and Wiessner (2011). Same norms were manifested by the IP of Lumutan.

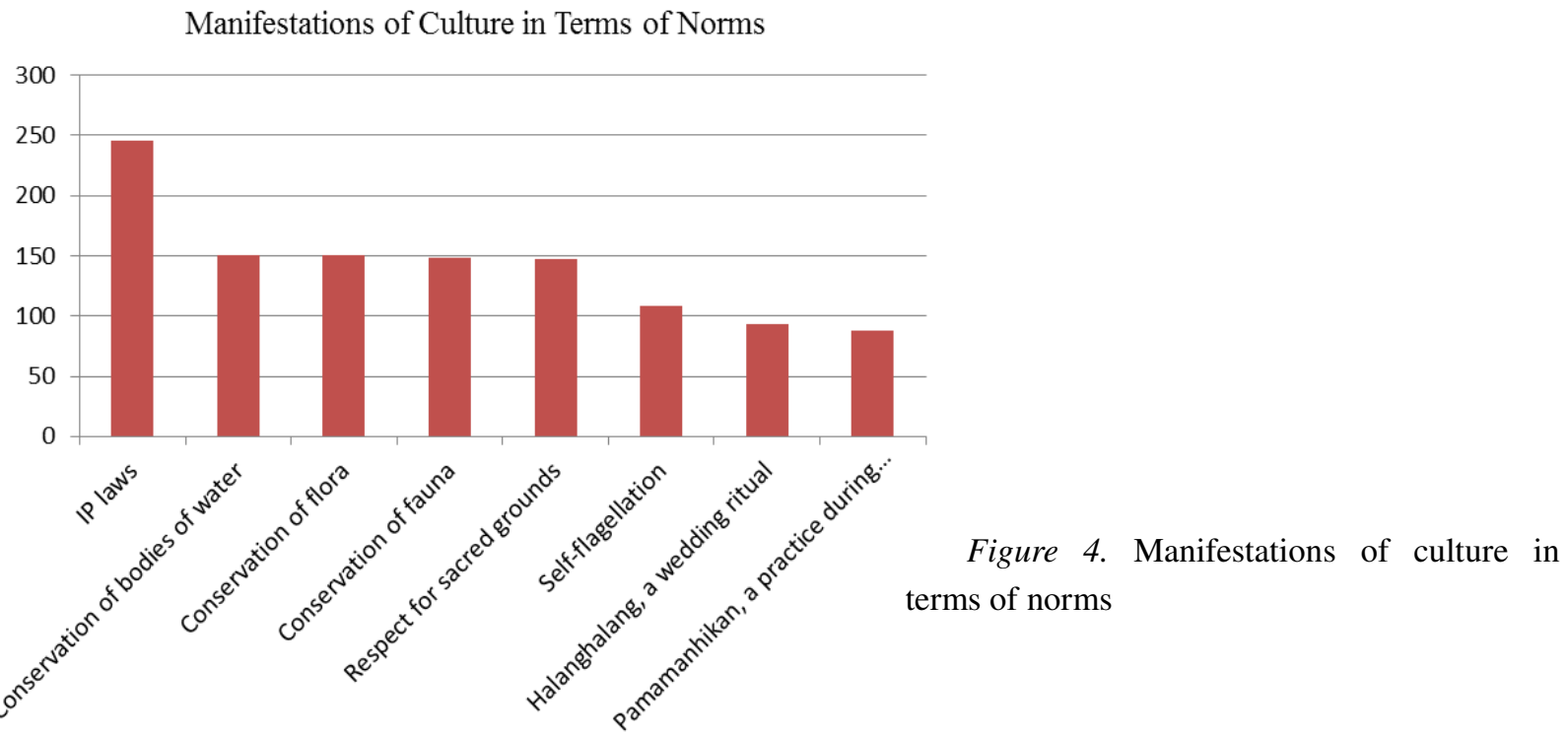

Manifestations of culture in terms of knowledge, beliefs, values and norms indicates behaviors and actions that mostly signify IP closeness to and dependence on nature as well as possession of communalist and animist traits.

Table 1 shows cultural integrity in terms of Knowledge with "knowledge of the land and waters of the barangay" acquiring a mean of 3.10 which was interpreted as somewhat high coupled with a standard deviation (SD) of .29. "Knowledge of natural resources including flora and fauna" had a mean of 3.03 interpreted as somewhat high with an SD of .18. "Knowledge of climate and weather" had a mean of 3.00 interpreted as somewhat high with an SD of .06. 
Manifestations of culture and cultural integrity of indigenous people

"Application of knowledge of the land and waters of the barangay" had a mean of 3.00 interpreted as somewhat high with an SD .06. "Application of knowledge of natural resources including flora and fauna" had a mean of 3.00 interpreted as somewhat high with an SD of 0.06. "Application of knowledge of climate and weather" had a mean of 3.00 interpreted as somewhat high with an SD of .06. "Knowledge of the Creator and other unseen beings" had a mean of 2.94 interpreted as somewhat high with an SD of 0.24. "Knowledge of the afterlife or the other world" had a mean of 2.73 interpreted as somewhat high with an SD 0.45. "Knowledge of forces or events that cannot be explained by science or reason" had a mean of 2.67 interpreted as somewhat high with an SD of 0.47. "Application of knowledge of the Creator and other unseen beings" had a mean of 2.90 interpreted as somewhat high with a SD of 0.41 . "Application of knowledge of the afterlife or other world" had a mean of 2.45 interpreted as somewhat low with an SD of 0.57. "Application of knowledge of forces or events that cannot be explained by science or reason" had a mean of 2.41 interpreted as somewhat low with as SD of 0.57. In total, cultural integrity in terms of Knowledge had a mean of 2.85 which was interpreted as somewhat high and an SD of 0.16. Because all of the SDs in Knowledge were lower than the means, mean responses of the IP indicated significant homogeneity.

The somewhat low findings in the "application of knowledge of the afterlife or other world" and "application of knowledge of forces or events that cannot be explained by science or reason" may be attributed to the intrusions of various organized religions and their teachings in Lumutan. Such situation is in agreement with the articulations of Anthony (2019) concerning diversity of religions.

\section{Table 1}

Cultural integrity in terms of knowledge

\begin{tabular}{|c|c|c|c|}
\hline Indicator & Mean & $S D$ & $\begin{array}{l}\text { Descriptive } \\
\text { interpretation }\end{array}$ \\
\hline 1. Knowledge of the land and waters of the barangay & 3.10 & 0.29 & Somewhat High \\
\hline $\begin{array}{l}\text { 2. Knowledge about the ecology (including flora and fauna) of the } \\
\text { barangay }\end{array}$ & 3.03 & 0.18 & Somewhat High \\
\hline 3. Knowledge of climate and weather & 3.00 & 0.06 & Somewhat High \\
\hline 4. Application of the knowledge of the land and waters of the barangay & 3.00 & 0.06 & Somewhat High \\
\hline $\begin{array}{l}\text { 5. Application of the knowledge about the ecology (including flora and } \\
\text { fauna) of the barangay }\end{array}$ & 3.00 & 0.06 & Somewhat High \\
\hline 6. Application of the knowledge of climate and weather & 3.00 & 0.06 & Somewhat High \\
\hline 7. Knowledge of the Creator and other unseen beings & 2.94 & 0.24 & Somewhat High \\
\hline 8. Knowledge of the afterlife or the other world & 2.73 & 0.45 & Somewhat High \\
\hline $\begin{array}{l}\text { 9. Knowledge of forces or events that cannot be explained by science or } \\
\text { reason }\end{array}$ & 2.67 & 0.47 & Somewhat High \\
\hline 10. Application of knowledge of the Creator and other unseen beings & 2.90 & 0.41 & Somewhat High \\
\hline 11. Application of knowledge of the afterlife or the other world & 2.45 & 0.57 & Somewhat Low \\
\hline $\begin{array}{l}\text { 12. Application of knowledge of forces or events that cannot be explained } \\
\text { by science or reason }\end{array}$ & 2.41 & 0.57 & Somewhat Low \\
\hline Cultural integrity in terms of knowledge & 2.85 & 0.16 & Somewhat High \\
\hline
\end{tabular}

Table 2 shows cultural integrity in terms of Beliefs with "belief in the way society or community is governed" garnering a mean of 2.92 which was interpreted as somewhat high coupled with an SD of 0.29. "Belief in the development path of society or community" had a mean of 2.94 interpreted as somewhat high with an SD of 0.29. "Belief in the true religion" had a mean of 3.00 interpreted as somewhat high with an SD of 0.19. In total, cultural integrity in terms of Beliefs had a mean of 2.95 which was interpreted as somewhat high with an SD of 0.19. Because all of the SDs in Beliefs were lower than the means, mean responses were indicative of considerable similarities in the responses of the IPs.

Similar to the articulations of Anthony (2019), Latayan, Cervantes, and Silao (2014), Stavropoulos (2019), and Wiessner (2011) on IP communities, the present research shows the IP of Lumutan as a community with unified political, economic and religious beliefs that were in harmony with the human and natural environment. 
Table 2

Cultural integrity in terms of beliefs

\begin{tabular}{|c|c|c|c|c|}
\hline Indicator & & Mean & $S D$ & $\begin{array}{c}\text { Descriptive } \\
\text { interpretation }\end{array}$ \\
\hline 13. Belief in the way society or community is governed & & 2.92 & 0.29 & Somewhat High \\
\hline 14. Belief in the development path of society or community & & 2.94 & 0.29 & Somewhat High \\
\hline 15. Belief in the true religion & & 3.00 & 0.19 & Somewhat High \\
\hline & Beliefs & 2.95 & 0.19 & Somewhat High \\
\hline
\end{tabular}

Note. 1.00-1.72 - Low, 1.73-2.48 - Somewhat Low, 2.49-3.24 - Somewhat High, and 3.25-4.00 - High.

Table 3 shows cultural integrity in terms of Values with "value for good relationship and intermingling with others" having a mean of 3.02 interpreted as somewhat high with an SD of 0.13 . "Value for order and preservation of ecology" had a mean of 2.91 interpreted as somewhat high with an SD of 0.28. "Value for life and spirits residing in living and non-living things" had a mean of 2.90 interpreted as somewhat high with an SD of 0.33. In total, cultural integrity in terms of Values had a mean of 2.94 interpreted as somewhat high with an SD of 0.20. Since all the SDs in Values were lower than the means, mean responses of the IP had considerable similarities.

The values for good relationships with human and non-human entities and the physical environment of the IPs being mentioned in the works of Anthony (2019), Latayan, Cervantes, and Silao (2014), Stavropoulos (2019), and Wiessner (2011) bear similarities with the values showing somewhat high cultural integrity. These values originated from IP knowledge and beliefs which served as the basic assumptions mentioned by Spencer-Oatey (2012) in her discussion of the layers of culture.

\section{Table 3}

Cultural integrity in terms of values

\begin{tabular}{|c|c|c|c|}
\hline Indicator & Mean & $S D$ & $\begin{array}{l}\text { Descriptive } \\
\text { interpretation }\end{array}$ \\
\hline 16. Value for good relationship and intermingling with others & 3.02 & 0.13 & Somewhat High \\
\hline 17. Value for order and preservation of ecology & 2.91 & 0.28 & Somewhat High \\
\hline 18. Value for life and spirits residing in living and non-living things & 2.90 & 0.33 & Somewhat High \\
\hline Values & 2.94 & 0.20 & Somewhat High \\
\hline
\end{tabular}

Note. 1.00-1.72 - Low, 1.73-2.48 - Somewhat Low, 2.49-3.24 - Somewhat High, and 3.25-4.00 - High.

Table 4 shows cultural integrity in terms of Norms with "rule of IP law" having a mean of 2.95 which was interpreted as somewhat high coupled with an SD of 0.34. "Observance of IP folkways" had a mean of 2.89 interpreted as somewhat high with an SD of 0.32. "Observance of IP mores" had a mean of 3.03 interpreted as somewhat high with an SD of 0.21. In total, cultural integrity in terms of Norms had a mean of 2.96 interpreted as somewhat high with an SD of 0.21. Since all the SDs in Norms were lower than the means, mean responses of the IP had considerable homogeneity. Similar to the findings of Legros and Cislaghi (2019), this present research show and classify norms of the IP. However, the classifications of norms considered in this research are IP laws, folkways and mores whereas in the research of Lesgros and Cislaghi (2019) norms were classified as individual or collective constructs, norms as affecting people actions, norms as how they form, survive and dissipate, and, lastly, norms as affected by groups.

\section{Table 4}

Cultural integrity in terms of norm

\begin{tabular}{lcccc}
\hline \multicolumn{1}{c}{ Indicator } & Mean & $S D$ & $\begin{array}{c}\text { Descriptive } \\
\text { interpretation }\end{array}$ \\
\hline 19. Rule of IP law & 2.95 & 0.34 & Somewhat High \\
20. Observance of IP folkways & Norms & 2.89 & 0.32 & Somewhat High \\
21. Observance of IP mores & 3.03 & 0.21 & Somewhat High \\
& Som & 0.21 & Somewhat High \\
\hline
\end{tabular}

Note. 1.00-1.72 - Low, 1.73-2.48 - Somewhat Low, 2.49-3.24 - Somewhat High, and 3.25-4.00 - High. 
Table 5 shows that correlation between manifestations of culture and cultural integrity in terms of Knowledge was .620 with a $p$-value of .000 indicating statistical significance at alpha .01 and was interpreted as high. Correlation between manifestations of culture in terms of Knowledge and cultural integrity in terms of Beliefs was .484 with a $p$-value of .000 indicating significance at alpha .01 and was interpreted as moderate. Interpreted as low, correlation between manifestations of culture in terms of Knowledge and cultural integrity in terms of Values was .389 with a $p$-value of .000 indicative of statistical significance at alpha .01. Correlation between manifestations of culture in terms of Knowledge and cultural integrity in terms of Norms was .424 with a $p$-value of .000 indicating statistical significance at alpha .01 and was interpreted as moderate.

The low correlation between manifestations of culture in terms of Knowledge and cultural integrity in terms of Values may have been due to the somewhat low findings in the "application of knowledge of the afterlife or the other world" and "application of knowledge of forces or events that cannot be explained by science or reason" which were in contrast with the somewhat high findings in "value for good relationship and intermingling with others", "value for order and preservation of ecology", and "value for life and spirits residing in living and non-living things."

Correlation between manifestations of culture in terms of Beliefs and cultural integrity in terms of Knowledge was .433 with a $p$-value of .000 indicating statistical significance at alpha .01 and was interpreted as moderate. Correlation between manifestations of culture and cultural integrity in terms of Beliefs was .609 with a $p$-value of .000 indicating significance at alpha .01 and was interpreted as high. Interpreted as high, correlation between manifestations of culture in terms of Beliefs and cultural integrity in terms of Values was .601 with a $p$-value of .000 indicative of statistical significance at alpha .01. Correlation between manifestations of culture in terms of Beliefs and cultural integrity in terms of Norms was .423 with a $p$-value of .000 indicating statistical significance at alpha .01 and was interpreted as moderate.

Correlation between manifestations of culture in terms of Values and cultural integrity in terms of Knowledge was .681 with a $p$-value of .000 indicating statistical significance at alpha .01 and was interpreted as high. Correlation between manifestations of culture in terms of Values and cultural integrity in terms of Beliefs was .549 with a $p$-value of .000 indicating significance at alpha .01 and was interpreted as moderate. Interpreted as moderate, correlation between manifestations of culture and cultural integrity in terms of Values was .517 with a $p$-value of .000 indicative of statistical significance at alpha .01. Correlation between manifestations of culture in terms of Values and cultural integrity in terms of Norms was .607 with a $p$-value of .000 indicating statistical significance at alpha .01 and was interpreted as high.

Correlation between manifestations of culture in terms of Norms and cultural integrity in terms of Knowledge was .638 with a $p$-value of .000 indicating statistical significance at alpha .01 and was interpreted as high. Correlation between manifestations of culture in terms of Norms and cultural integrity in terms of Beliefs was .614 with a $p$-value of .000 indicating significance at alpha .01 and was interpreted as high. Interpreted as moderate, correlation between manifestations of culture in terms of Norms and cultural integrity in terms of Values was .508 with a $p$-value of .000 indicative of statistical significance at alpha .01 . Correlation between manifestations of culture and cultural integrity in terms of Norms was .564 with a $p$-value of .000 indicating statistical significance at alpha .01 and was interpreted as moderate.

The significant relationships and the positive correlations between variables reinforce the assumptions of Latayan (2020) and Root (2018) concerning the interrelation of manifestations of culture and cultural integrity. Thus, the assumption that an increase in the occurrence of manifestations of culture results to an intensified cultural integrity and vice-versa is strengthened. Revitalizing an element of IP culture may, therefore, revitalize the other elements. 
Latayan, J. C., \& Tan, C. S.

\section{Table 5}

Significant relationship between manifestations of culture and cultural integrity

\begin{tabular}{|c|c|c|c|c|}
\hline Variables & $\begin{array}{l}\text { Cultural Integrity } \\
\text { Knowledge }\end{array}$ & $\begin{array}{l}\text { Cultural Integrity } \\
\text { Beliefs }\end{array}$ & $\begin{array}{c}\text { Cultural Integrity } \\
\text { Values }\end{array}$ & $\begin{array}{c}\text { Cultural Integrity } \\
\text { Norms }\end{array}$ \\
\hline \multirow{3}{*}{$\begin{array}{c}\text { Manifestations of Culture } \\
\text { Knowledge }\end{array}$} & $.620^{* *}$ & $.484^{* *}$ & $.389^{* *}$ & $.424^{* *}$ \\
\hline & .000 & .000 & .000 & .000 \\
\hline & High & Moderate & Low & Moderate \\
\hline \multirow{3}{*}{$\begin{array}{c}\text { Manifestations of Culture } \\
\text { Beliefs }\end{array}$} & $.433^{* * *}$ & $.609^{* * *}$ & $.601^{* * *}$ & $.423^{* * *}$ \\
\hline & .000 & .000 & .000 & .000 \\
\hline & Moderate & High & High & Moderate \\
\hline \multirow{3}{*}{$\begin{array}{c}\text { Manifestations of Culture } \\
\text { Values }\end{array}$} & $.681^{* *}$ & $.549^{* *}$ & $.517^{* *}$ & $.607^{* *}$ \\
\hline & .000 & .000 & .000 & .000 \\
\hline & High & Moderate & Moderate & High \\
\hline \multirow{3}{*}{$\begin{array}{c}\text { Manifestations of Culture } \\
\text { Norms }\end{array}$} & $.638^{* *}$ & $.614^{* *}$ & $.508^{* * *}$ & $.564^{* *}$ \\
\hline & .000 & .000 & .000 & .000 \\
\hline & High & High & Moderate & Moderate \\
\hline
\end{tabular}

Note. $* * p<.01$.

\section{Conclusion}

From the findings of research, the following conclusions are drawn:

There are significant relationships between manifestations of culture and cultural integrity in terms of IP knowledge, beliefs, values, and norms. Therefore, the null hypothesis is rejected. Cultural revitalization efforts of the IP and concerned agencies may prioritize revitalizing IP knowledge particularly those concerning spiritual and religious rituals and practices. Future researchers on cultural manifestations, cultural integrity and other similar topics may replicate and apply the framework and methodology of this research be it on IP or non-IP settings. Moreover, future researchers are advised to include other cultural elements such as artifacts and language as variables of manifestations of culture and cultural integrity.

\section{References}

Amar, A. G. (2019). The indigenous peoples education curriculum framework. Press Reader.

Anthony, D. (2019). Religious beliefs in the Philippines. Retrieved from http://WorldAtlas.worldatlas.com/articles/religious-beliefs-in-the-philippines.html

Bulgan, A. C. (2014). Culture. Retrieved from http://AdrianChristianBulgan/chapter-3-37865378 https://doi.org/10.1515/hgjb-2014-0135

Del Castillo, F. (2013). Teaching values using creative strategies. Manila: Great Books Publishing.

Hofstede, G., Hofstede, G. J., \& Minkov, M. (2010). Cultures and organizations: Software of the mind (3rd ed.). New York, NY: McGraw-Hill.

Kingston, L. (2015). The destruction of identity: Cultural genocide and indigenous peoples. Journal of Human Rights, 14(1), 63-83. https://doi.org/10.1080/14754835.2014.886951

Latayan, J. C. (2020). Manifestations of culture, cultural integrity, and demographic profile: Inputs to an enhanced indigenous people basic education curriculum in araling panlipunan. College of Teacher Education, Laguna State Polytechnic University- Los Baños Campus, Los Baños, Laguna.

Latayan, J. C., Cervantes, P. M. C.; \& Silao, J. D. (2014). Cultural integrity rights, community development and quality of life of an indigenous people community. Searchlight, 35-48.

Legros, S., \& Cislaghi, B. (2019). Mapping the social-norms literature: An overview of reviews. Perspectives of Psychological Science, 15(1), 62-80. https://doi.org/10.1177/1745691619866455

Lenkeit, R. E. (2011). Introduction to cultural anthropology. New York: McGraw-Hill.

Manongdo, P. (2018). How the poorest of the poor champion sustainability. Retrieved from https://www.eco-business.com/news/how-the-poorest-of-the-poor-champion-sustainability/

Panopio, I. S. (2006). Society and culture: Introduction to sociology and anthropology (Rev. 3rd ed.). JMC Press. Root, D. (2018). Cannibal culture art, appropriation, and the commodification of difference. New York: Taylor

70 Consortia Academia Publishing (A partner of Network of Professional Researchers and Educators) 
and Francis Books https://doi.org/10.4324/9780429501890

Rose, J. (2016). Biopiracy: When indigenous knowledge is patented for profit. The Conversation. Retrieved from https://theconversation.com/biopiracy-when-indigenous-knowledge -is-patented-for-profit-55589

SIL Philippines. (2019). Ethnologue. https://philippines.sil.org/resources

Spencer-Oatey, H. (2012). What is culture? A compilation of quotations. GlobalPAD Core Concepts.

Stavropoulos, P. (2019). Indigenous Values. Woodbine Ecology Center. Denver, Colorado.

Watene, K., \& Yap, M. (2018). Culture and sustainable development: indigenous contributions. Journal of Global Ethics, 11(1), 55-55. https://doi.org/10.1080/17449626.2015.1010099

Wiessner, S. (2011). The cultural rights of indigenous peoples: Achievements and continuing challenges. European Journal of International Law, 22(1), 121-140. https://doi.org/10.1093/ejil/chr007 
Latayan, J. C., \& Tan, C. S.

72 Consortia Academia Publishing (A partner of Network of Professional Researchers and Educators) 